\title{
PENGARUH PERTUMBUHAN PENJUALAN TERHADAP PROFITAILITAS PADA PT.GUDANG GARAM TBK
}

\author{
Purnama Putri Sya'dah \\ Sekolah Tinggi Ilmu Ekonomi (STIE) Bima \\ Email:Putri05.stie@gmail.com \\ Nurul Huda \\ Sekolah Tinggi Ilmu Ekonomi (STIE) Bima \\ Email:Nurulhuda.stiebima@gmail.com
}

\begin{abstract}
Purpose of this research is to know the influence of sales growth to profitability in PT. Gudang Garam Tbk. The population of this research is the financial report of sales growth and net profit in PT. Gudang Garam TBK, for 10 years IE 2009-2018. The sample will be the financial report of sales growth and net profit in PT. Gudang Garam, for 5 years which is $2014-2018$. This is an associative research with sampling techniques that is purposive sampling. The test results showed that there was no significant influence between sales growth on profitability at PT Gudang Garam Tbk. With a value of R2 of $16.1 \%$.
\end{abstract}

Keywords: Sales growth, profitability

\begin{abstract}
Abtrak
Tujuan penelitian ini adalah untuk mengetahui pengaruh pertumbuhan penjualan terhadap profitabilitas pada PT. Gudang Garam Tbk. Populasi penelitian ini adalah laporan keuangan pertumbuhan penjualan dan laba bersih pada PT. Gudang Garam Tbk, selama 10 tahun yaitu tahun 2009 - 2018. Sampel yang diguakan adalah laporan keuangan pertumbuhan penjualan dan laba bersih pada PT. Gudang Garam, selama 5 tahun yaitu tahun 2014 - 2018. Peneliian ini merupakan penelitian asosiatif dengan tehnik sampling yaitu purposive sampling. Hasil pengujian menunjukkan bahwa tidak ada pengaruh yang signifikan antara pertumbuhan penjualan terhadap profitabilitas pada PT Gudang Garam Tbk. Dengan nilai R2 sebesar 16,1\%.
\end{abstract}

Kata Kunci : Pertumbuhan Penjualan, Profitabilitas 
Invoice: Jurnal Ilmu Akuntansi

p-ISSN: 2714-6359 e-ISSN: 2714-6340

Vol.2 Nomor 2 September 2020

\section{PENDAHULUAN}

Perekonomian yang semakin pesat merupakan suatu tantangan sekaligus peluang bagi perusahaan untuk selalu melakukan penyesuaian terutama dalam hal kebijakan agar perusahaan dapat menjawab tantangan, peluang dan dapat bersaing dalam dunia perindustrian. Dalam menghadapi persaingan tersebut, perusahaan dituntut untuk mempunyai keunggulan bersaing baik dalam hal produk yang dihasilkan, sumber daya manusia, maupun teknologi yang digunakan. Namun, untuk memiliki keunggulan itu semua, perusahaan membutuhkan dana yang semakin besar, serta terus berupaya meningkatkan profit perusahaan.

Pertumbuhan penjualan merupakan perubahan penjualan pada laporan keuangan pertahun pada PT Gudang Garam Tbk. Perubahan penjualan yang di atas rata-rata bagi suatu perusahaan umumnya didasarkan pada pertumbuhan yang cepat yang diharapkan dari industri dimana perusahaan itu beroperasi.

Pertumbuhan penjualan merupakan rasio yang dapat digunakan untuk menggambarkan kenaikan penjualan perusahaan tahun inidi bandingkan penjiualan tahun lalu. Proksi yang digunakan dalam penelitian ini adalah growth yaitu selisih antara jumlah antara periode ini dengan periode sebelumnya dibandingkan dengan penjualan periode sebelumnya.

Profitabilitas mempunyai arti penting bagi perusahaan karena merupakan salah satu dasar untuk penilaian kondisi suatu perusahaan. Tingkat profitabilitas menggambarkan kinerja perusahaan yang dilihat dari kemampuan perusahaan menghasilkan profit. Kemampuan perusahaan memperoleh profit ini menunjukkan apakah perusahaan mempunyai prospek yang baik atau tidak dimasa yang akan datang. Profitabilitas dalam penelitian ini diproksikan dengan return on asset (ROA) karena dapat menunjukkan bagaimana kinerja perusahaan dilihat dari penggunaan keseluruhan aset yang dimiliki oleh perusahaan dalam menghasilkan keuntungan.

Penjualan merupakan kriteria penting untuk menilai profitabilitas perusahaan dan merupakan indikator utama atas aktivitas perusahaan (Andrayani, 2013). Pertumbuhan penjualan adalah kenaikan jumlah penjualan dari tahun ke tahun atau dari waktu ke waktu (Kennedy dkk., 2013). Pertumbuhan penjualan memiliki pengaruh yang strategis bagi perusahaan karena pertumbuhan penjualan ditandai dengan peningkatan market share yang akan berdampak pada peningkatan penjualan dari perusahaan sehingga akan meningkatkan profitabilitas dari perusahaan (Pagano dan Schivardi, 2013). Laba yang dihasilkan perusahaan erat hubungannya dengan tingkat profitabilitas perusahaan itu sendiri. Rasio profitabilitas menggambarkan kemampuan perusahaan mendapatkan laba melalui semua kemampuan dan sumber yang ada seperti kegiatan penjualan, kas, modal, jumlah karyawan, jumlah cabang, dan sebagainya (Harahap, 2011). Profitabilitas yang tinggi menunjukkan semakin efektif perusahaan dalam menjalankan operasinya sehingga mampu meningkatkan laba yang optimal.

Sebaliknya, profitabilitas yang rendah menggambarkan bahwa perusahaan kurang efisien dalam menjalankan operasinya sehingga kurang mampu menghasilkan laba yang optimal. 
Invoice: Jurnal Ilmu Akuntansi

p-ISSN: 2714-6359 e-ISSN: 2714-6340

Vol.2 Nomor 2 September 2020

PT. Gudang Garam Tbk. Dalam pencapaian tujuan perusahaan yaitu menghasilkan laba, maka setiap produk yang dihasilkan tersebut dijual kepada pelanggan. Penjualan menjadi kegiatan utama untuk memperoleh pendapatan sehingga laba perusahaan dapat dioptimalkan. Penjualan tersebut dapat berlangsung dengan adanya modal kerja yang membiayainya. Sehingga, penjualan menjadi faktor untuk menghasilkan laba perusahaan. Berikut adalah data penjualan dan laba bersih PT. Gudang Garam Tbk tahu 2015-2018 :

Tabel 1. Data Penjualan dan Laba Bersih PT. Gudang Garam Tbk, Tahun 2015-2018 (Dalam ribuan rupiah)

\begin{tabular}{|c|c|c|}
\hline Tahun & Penjualan (x) & Laba Bersih (y) \\
\hline 2015 & 2.474 .623 & 253.664 \\
\hline 2016 & 4.056 .735 & 346.728 \\
\hline 2017 & 5.139 .974 & 378.142 \\
\hline 2018 & 6.010 .895 & 373.750 \\
\hline Jumlah & 17.955 .227 & 1.352 .284 \\
\hline
\end{tabular}

Sumber : Data sekunder

Dari tabel 1, dapat diketahui bahwa penjualan PT. Gudang Garam Tbk tahun 2015-2018 mengalami peningkatan. Hal tersebut berarti PT. Gudang Garam, Tbk tahun 2015-2018 memiliki kinerja yang baik dilihat dari segi penjualan. Peningkatan pada penjualan yang tidak disertai pada peningkatan laba bersih menimbulkan dugaan bahwa ada pengaruh secara signifikan. Keadaan tersebut dikhawatirkan dapat mempengaruhi tingkat profitabilitas perusahaan. Oleh karena itu, dengan adanya peningkatan penjualan ini apakah dapat memicu perubahan pada profitabilitas perusahaan, yang mana perubahan tersebut menentukan kinerja perusahaan yang dicapai pada periode bersangkutan.

Berdasarkan uraian dari latar belakang tersebut, maka yang menjadi pokok permasalahan pada penelitian ini adalah: Adakah pengaruh Pertumbuhan Laba terhadap Profitabilitas pada PT. Gudang Garam Tbk ?.

\section{TINJAUAN PUSTAKA}

\subsection{Pertumbuhan Penjualan}

Pertumbuhan penjualan merupakan perubahan penjualan pada laporan keuangan pertahun. Pertumbuhan penjualan yang di atas rata-rata bagi suatu perusahaan umumnya didasarkan pada pertumbuhan yang cepat yang diharapkan dari industri dimana perusahaan itu beroperasi. Pertumbuhan atas penjualan merupakan salah satu hal penting atas produk dan jasa perusahaan tersebut dari penerimaan pasar, dimana untuk mengukur tingkat pertumbuhan penjualan tersebut adalah dari pendapatan yang dihasilkan atas penjualan tersebut (Taufiqurahman, Syaraswati dan Puspita, 2012 : 122). Berkaitan dengan pertumbuhan penjualan, perusahaan harus memiliki strategi yang tepat untuk memenangkan dan dapat bersaing agar dapat menarik konsumen untuk selalu memilih produknya. Tingkat pertumbuhan suatu perusahaan akan dapat berpengaruh terhadap kemampuan perusahaan dalam mempertahankan keuntungan yang telah diperoleh untuk menandai kesempatan- 
Invoice: Jurnal Ilmu Akuntansi

p-ISSN: 2714-6359 e-ISSN: 2714-6340

Vol.2 Nomor 2 September 2020

kesempatan pada masa yang akan datang. Pertumbuhan penjualan yang tinggi, maka akan mencerminkan pendapatan meningkat sehingga pembayaran deviden cenderung meningkat. Perusahaan yang mempunyai keuntungan meningkat akan memiliki laba ditahan yang lebih besar. Peningkatan laba perusahaan dapat meningkatkan jumlah modal sendiri yang berasal dari laba ditahan.

Penjualan yang relatif stabil dan selalu meningkat pada sebuah perusahaan, memberikan kemudahan bagi perusahaan tersebut untuk dapat memperoleh aliran dana dari pihak eksternal atau hutang untuk meningkatkan operasionalnya. Pada waktu yang sama perusahaanperusahaan ini sering menghadapi ketidakpastian yang lebih besar, cenderung untuk mengurangi keinginan mereka untuk menggunakan hutang (Sjahrial Dermawan, 2014:303).Dengan demikian dapat diketahui bahwa suatu perusahaan dapat dikatakan mengalami pertumbuhan kearah yang lebih baik jika terdapat peningkatan yang konsisten dalam aktivitas utama operasinya.

\subsection{Profitabilitas}

Tingkat profitabilitas suatu perusahaan menjadi salah satu faktor yang harus dipertimbangkan dalam kebijakan struktur modal (Sartono, 2013 : 122). Perusahaan yang sangat menguntungkan pada dasarnya tidak membutuhkan biaya pembiayaan dengan hutang. Laba ditahan perusahaan yang tinggi sudah mencukupi untuk membiayai sebagian besar kebutuhan pendanaan. Brigham dan Houston (2011) menyatakan bahwa perusahaan yang memiliki tingkat pengembalian yang tinggi atas investasi maka perusahaan menggunakan hutang yang relatif kecil. Tingkat pengembalian yang tinggi memungkinkan perusahaan untuk membiayai sebagian besar kebutuhan dana dengan dana yang dihasilkan secara internal oleh perusahaan tersebut.Berdasarkan uraian diatasmemiliki kesimpulan, bahwa profitabilitas memiliki pengaruh terhadap struktur modal dengan dasar bahwa perusahaan yang memiliki profitabilitas yang tinggi akan mengurangi ketergantungannya pada pihak eksternalkarena tingkat keuntungan yang tinggi akan memungkinkan perusahaan untuk memperoleh sebagian besar pendanaannya dari laba ditahan. Hal ini akan berpengaruh terhadap penentuan komposisi struktur modal.

Menurut Agus Sartono (2010) mengemukakan tentang profitabilitas : "Profitabilitas adalah kemampuan perusahaan memperoleh laba dalam hubungannya dengan penjualan, total aktiva maupun modal sendiri". Profitabilitas atau kemampuan laba merupakan kemampuan perusahaan didalam menghasilkan laba. Profitabilitas mencerminkan keuntungan dari investasi keuangan. Myers dan Majluf (2017) berpendapat bahwa manajer keuangan yang menggunakan packing order theory dengan laba ditahan sebagai pilihan pertama dalam pemenuhan kebutuhan dana dan hutang sebagai pilihan kedua serta penerbitan saham sebagai pilihan ketiga, akan selalu memperbesar profitabilitas untuk meningkatkan laba.

Profitability ratio merupakan rasio untuk mengukur kemampuan perusahaan memperoleh laba dalam hubungannya dengan penjualan, total aktiva 12 maupun modal sendiri (Agus Sartono, 2013). Rasio ini sangat diperhatikan oleh calon investor maupun pemegang saham karena berkaitan dengan harga saham serta dividen yang akan diterima. 
Invoice: Jurnal Ilmu Akuntansi

p-ISSN: 2714-6359 e-ISSN: 2714-6340

Vol.2 Nomor 2 September 2020

Profitabilitas sebagai tolak ukur dalam menentukan alternatif pembiayaan, namun cara untuk menilai profitabilitas suatu perusahaan adalah bermacammacam dan sangat tergantung pada laba dan aktiva atau modal yang akan dibandingkan dari laba yang berasal dari opersai perusahaan atau laba netto sesudah pajak dengan modal sendiri. Dengan adanya berbagai cara dalam penelitian profitabilitas suatu perusahaan tidak mengherankan bila ada beberapa perusahaan yang mempunyai perbedaan dalam menentukan suatu alternatif untuk menghitung profitabilitas. Hal ini bukan keharusan tetapi yang paling penting adalah profitabilitas mana yang akan digunakan, tujuannya adalah sematamata sebagai alat mengukur efisiensi penggunaan modal di dalam perusahaan yang bersangkutan. Pertumbuhan penjualan merupakan perubahan kenaikan ataupun penurunan penjualan dari tahun ke tahun yang dapat dilihat pada laporan labarugi perusahaan. Perusahaan yang baik dapat dilihat dari penjualannya dari tahun ke tahun yang terus mengalami kenaikan, hal tersebut berimbas pada meningkatnya keuntungan perusahaan sehingga pendanaan internal perusahaan juga meningkat. Sedangkan menurut Rudianto (2014) menyatakan bahwa pertumbuhan penjualan merupakan volume penjualan pada tahun-tahun mendatang, berdasarkan data pertumbuhan volume penjualan historis.

\section{Hubungan Antara Variabel Pertumbuhan Penjualan Terhadap Profitabilitas}

Return on asset profibilitas memberikan ukuran tingkat efektivitas manajemen suatu perusahaan yang ditunjukkan dari laba yang dihasilkan dari pertumbuhan penjualan atau dari pendapatan investasi (kasmir, 2014). Semakin tinggi return on asset tersebut mampu menghasilkan pertumbuhan penjualan yang signifikan, sehingga dapat menunjukkan bahwa manajemen perusahaan mampu menggunakan asetnya secara produktif. Pendapatan yang stabil dan pengolahan aset yang efektif dan efisien akan mempengaruhi kemampuan perusahaan untuk tumbuh. Dengan adanya kemampuan tersebut, maka perusahaan dapat terus tumbuh dengan laba yang mampu ditingkatkan. Sebaliknya, jika return on asset suatu perusahaan rendah, perusahaan kurang mampu menghasilkan laba dikarenakan pertumbuhan penjualan perusahaan tidak efektif dalam mengelola asetnya.

\section{METODE PENELITIAN}

Jenis penelitian ini termasuk penelitian asosiatif, karena diajukan untuk menggambarkan atau melukiskan secara sistimatis dan akurat mengenai pengaruh antara variabel $\mathrm{X}$ dan variabel $\mathrm{Y}$. Populasi yang digunakan dalam penelitian ini yaitu laporan keuangan pertumbuhan penjualan dan laba bersih pada PT. Gudang Garam Tbk, selama 10 tahun mulai dari tahun 2009 sampai dengan tahun 2018. Sampel pada penelitian ini adalah laporan keuangan pertumbuhan penjualan dan laba bersih pada PT. Gudang Garam, selama 5 tahun yaitu mulai dari tahun 2014 sampai dengan tahun 2018. Peneliti menggunakan teknik purposive sampling yaitu tehnik penarikan sampel dengan pertimbangan tertentu. Teknik pengumpulan data yang digunakan dalam penelitian ini adalah metode dokumentasi dan studi pustaka. 


\subsection{Tehnik analisi data}

1. Regresi sederhana

Analisis Regresi Sederhana adalah sebuah metode pendekatan untuk pemodelan hubungan antara satu variabel dependen dan satu variabel independen. Dalam model regresi, variabel independen menerangkan variabel dependennya.

2. Analisis koefisien korelasi

Nilai koefisien korelasi merupakan nilai yang digunakan untuk mengukur kekuatan (keeratan) suatu hubungan antar variabel, (Nugroho, 2005). Koefisien korelasi memiliki nilai antara -1 hingga +1 . Sifat nilai koefisien korelasi adalah plus (+) atau minus (-). Hal ini menunjukkan ini arah korelasi.
3. Analisis koefisen determinasi

Koefisien Determinasi R Kuadrat $\left(\mathrm{R}^{\wedge} 2\right)$

Menurut Imam Ghozali (2009)

Koefisien Determinasi pada intinya mengukur seberapa jauh kemampuan sebuah model dalam menerangkan variasi variabel Dependen. Nilai Koefisien Determinasi adalah antara nol dan satu.

4. Ujit

Uji $\mathrm{T}$ (Test $\mathrm{T}$ ) adalah salah satu test statistik yang dipergunakan untuk menguji kebenaran atau kepalsuan hipotesis nihil yang menyatakan bahwa diantara dua buah mean sampel yang diambil secara random dari populasi yang sama, tidak terdapat perbedaan yang signifikan. (Sudjiono, 2010).

\begin{tabular}{|c|c|c|c|c|c|}
\hline \multirow[b]{3}{*}{ Model } & \multicolumn{5}{|c|}{$\begin{array}{l}\text { 4. HASIL DAN PEMBAHASAN } \\
\text { 4.1 Analisis Regresi Linier Sederhana } \\
\text { Coefficients }^{\mathrm{a}}\end{array}$} \\
\hline & \multicolumn{2}{|c|}{$\begin{array}{l}\text { Unstandardized } \\
\text { Coefficients }\end{array}$} & \multirow{2}{*}{$\begin{array}{l}\text { Standardized } \\
\text { Coefficients } \\
\text { Beta }\end{array}$} & \multirow[b]{2}{*}{$\mathrm{t}$} & \multirow[b]{2}{*}{ Sig. } \\
\hline & B & Std. Error & & & \\
\hline 1 (Constant) & ,116 & ,014 & & 8,556 & ,003 \\
\hline PERTUMBUHAN PENJUALAN &,- 084 & ,110 &,- 401 &,- 758 & ,504 \\
\hline
\end{tabular}

a. Dependent Variable: ROA

Persamaan regresi linear sederhana

$\mathrm{Y}=0,116-0,084 \mathrm{X}$

a. konstanta, $\mathrm{a}=0.116$ artinya jika pertumbuhan penjualan konstan atau sama dengan nol maka profitabilitas akan naik sebesar 0,116. b. koefisien variabel $b=-0,084$ artinya jika pertumbuhan penjualan naik sebesar Rp.1 maka profitabiitas akan turun sebesar 0,084

\begin{tabular}{l|r|r|r|r|r}
\multicolumn{7}{c}{ Uji t } \\
\multicolumn{1}{c|}{$\begin{array}{c}\text { Coefficients } \\
\text { Unstandardized } \\
\text { Coefficients }\end{array}$} & $\begin{array}{c}\text { Standardized } \\
\text { Coefficients }\end{array}$ & & \\
Model & B & Std. Error & Beta & t & \multicolumn{1}{c}{ Sig. } \\
\hline 1 (Constant) &, 116 &, 014 & & 8,556 &, 003 \\
\hline PERTUMBUHAN PENJUALAN &,- 084 &, 110 &,- 401 &,- 758 &, 504 \\
\hline
\end{tabular}

a. Dependent Variable: ROA 
Invoice: Jurnal Ilmu Akuntansi

p-ISSN: 2714-6359 e-ISSN: 2714-6340

Vol.2 Nomor 2 September 2020

Berdasarkan hasil olahan data olahan data maka dapat di simpulkan sebagai berikut; Nilai t hitung sebesar $-0,758$ dan $t$ tabel sebesar 3,182 dengan nilai signifikan sebesar 0,504 sehingga dapat disimpulkan tidak ada pengaruh yang signifikan antara pertumbuhan penjualan terhadap profitabilitas pada PT. Gudang Garam Tbk.

Analisi koefisien korelasi Model Summary

\begin{tabular}{ll|r|r|r} 
Model & $\mathrm{R}$ & R Square & \multicolumn{1}{|c|}{$\begin{array}{c}\text { Adjusted R } \\
\text { Square }\end{array}$} & $\begin{array}{c}\text { Std. Error of the } \\
\text { Estimate }\end{array}$ \\
\hline 1 &, $401^{\mathrm{a}}$ &, 161 &,- 119 &, 009667 \\
\hline
\end{tabular}

a. Predictors: (Constant), PERTUMBUHAN PENJUALAN

Nilai koefisien koefisien korelasi linear pertumbuhan penjualan dan profitabilitas sederhana yaitu sebesar 0,401 artinya pada PT GUDANG GARAM TBK sedang. tingkat keeratan hubungan antar

\section{Analisis koefisien determinasi Model Summary}

\begin{tabular}{ll|r|r|r} 
Model & $\mathrm{R}$ & R Square & \multicolumn{1}{c|}{$\begin{array}{c}\text { Adjusted R } \\
\text { Square }\end{array}$} & $\begin{array}{c}\text { Std. Error of the } \\
\text { Estimate }\end{array}$ \\
\hline 1 &, $401^{\mathrm{a}}$ &, 161 &,- 119 &, 009667 \\
\hline
\end{tabular}

a. Predictors: (Constant), PERTUMBUHAN PENJUALAN

Nilai koefisien determinasi atau $\mathrm{Kd}=$ 0,161 atau $16,1 \%$ artinya kontribusi pengaaruh pertumbuhan penjualan terhadap profitabilitas pada PT.GUDANG GARAM TBK yaitu sebesar $16.1 \%$ sedangkan sisanya $83,9 \%$ di pengaruhi oleh faktor-faktor lain yang yang tidak di teliti dalam penelitian ini.

\section{PENUTUP}

Tidak ada pengaruh yang signifikan antara pertumbuhan penjualan terhadap profitablitas pada PT.GUDANG GARAM TBK.

\section{DAFTAR PUSTAKA}

Andrayani, 2013 Dasar-Dasar Manajemen Keuangan. Alih Bahasa: Ali Akbar Yulianto. Edisi 11. Buku 1. Jakarta: Salemba Empat.

Agus $\begin{array}{rcc}\text { Sartono } & (2010) & \text { Kebijakan } \\ \text { Pendanaan } & \text { dan } & \text { Restruksi }\end{array}$

Perusahaan. Jakarta: PT Gramedia Pustaka.

Agus Sartono, (2013) How Firm Characteristics Affect Capital Structure: An International Comparison. The Journal of Financial Research. Vol. XXII, N0.2 Pages 16118.

Elfianto Nugroho (2012) Analisis Pengaruh Likuiditas, Pertumbuhan Penjualan, Perputaran Modal Kerja, Ukuran Perusahaan dan Leverage Terhadap Profitabilitas

Perusahaan (Studi pada Perusahaan Manufaktur yang Terdaftar pada BEI padaTahun 2007 - 2011.

Fabozzi (2011) Understanding Profitability. IOWA State University.

Harahap (2008) Manajemen Keuangan Teori dan Aplikasi. Edisi 4. Yogyakarta: BPFE.

Harahap, 2011 Pokok-Pokok Analisis Laporan Keuangan. Edisi Pertama. 
Cetakan Kedelapan. Yogyakarta: BPFE.

Harahap, $2013 \quad$ Dasar-Dasar Ekonometrika. Jakarta: Erlangga. Damodar N. Gujarati, Dawn C. Porter. Basic Econometrics. 5th Edition. New York: McGraw-Hill.

Inta Budi Setyanusa (2013) Pengaruh Likuiditas dan Struktur Modal Terhadap Profitabilitas (Studi Kasus Pada Perusahaan Manufaktur Sektor Food \& Beverage Yang Terdaftar Di Bursa Efek Indonesia Periode 20072012).

Irham fahmi (2012) Manajemen Investasi. Alih Bahasa: Tim Alih Bahasa Salemba Empat. Buku 2. Jakarta: Salemba Empat.

kasmir, (2014) Manajemen Keuangan. Jilid 2. Edisi 9. Binarupa Aksara.

Kennedy dkk., (2013) Dasar dasar Pembelanjaan Perusahaan. Edisi 4. Yogyakarta : Bagian Penerbitan FE.
Myers dan Majluf (2017) Pengaruh Tangibility, Pertumbuhan Penjualan, Ukuran Perusahaan Terhadap Struktur Keuangan. Jurnal Bisnis dan Akuntansi . Vol 10 No. 1.

Pagano dan Schivardi, 2013 Pengaruh Profitabilitas, Pertumbuhan Penjualan, Struktur Aset dan Tingkat Pertumbuhan Terhadap Struktur Modal. Jurnal Ilmu dan Riset Akuntansi. Vol 3 No 7.

Rudianto (2014) Pengaruh Profitabilitas, Tingkat Pertumbuhan Perusahaan, Likuiditas, Dan Pajak Terhadap Struktur Modal Pada Sektor Pariwisata. E Jurnal Manajemen Unud, Vol. 5 No 6

Sudjiono, (2010) Dasar-dasar Manajemen Keuangan. Edisi 11 Buku 2. Jakarta : Salemba Empat. 